it is important to send synovial tissue for culture as well as histological examination. ${ }^{1}$

$M$ kansasii is frequently resistant to standard antituberculous agents in vitro but may respond to these agents in vivo. ${ }^{23}$ In most reported cases combination antituberculous therapy has been used and continued for 1.5-2 years, ${ }^{124}$ sometimes with synovectomy and joint irrigation. ${ }^{35}$ Our experience suggests that such long term and aggressive treatment may not be needed in an undamaged joint.

A good response to only three months' triple therapy has been reported in a patient with tenosynovitis due to $M$ kansasii, the duration of therapy again being limited by toxic reactions. ${ }^{4}$ Triple therapy is sometimes inadequate, as in our case, and agents such as pyrazinamide or erythromycin may have to be added. ${ }^{3}$ Patients should be monitored clinically, but thermography offers a useful objective measure of response. Once this has been achieved it may be necessary to continue treatment for only six months at most.

We thank Mr M H Matthewson, Dr T Higenbottam, Dr G Neale, and Dr S Stone for their help with this patient; Mr G Parr in the Addenbrooke's Hospital rheumatology research unit for the thermography; and the Tuberculosis Reference Laboratory, Cardiff for the susceptibility test results.

' Saphyakhajon P, Mukhopadhyay D, Spiegel P, et al. Mycobacterium kansasii:

' Parker MD, Irwin RS. Mycobacterium kansasii: tendinitis and fasciitis. $\mathcal{F}$ Bone Foint Surg 1975;57-A:557-9.

e Meriux P, Keystone EC, Hutcheon M, et al. Polyarthritis due to Mycobacterium kansasii in a patient with rheumatoid arthritis. Ann Rheum Dis 1980;

Leader M, Revell P, Clarke G. Synovial infection with Mycobacterium kansasii. Am Rheum Dis $1984 ; 43: 80-2$.

RJ, et al. Musculoskeletal infections due to Mycobacterium kansasii. Clin Orthop 1978;136:244-6.

Addenbrooke's Hospital, Cambridge CB2 2QQ

$S$ R CARROLL, MB, BS, senior house officer in rheumatology and rehabilitation

$S$ W B NEWSOM, MD, FRCPATH, consultant microbiologist

J R JENNER, MD, MRCP, consultant in rheumatology and rehabilitation

Correspondence to: Dr J R Jenner.

\section{Stress reduction by oxprenolol and placebo: controlled investigation of the pharmacological and non-specific effects}

At least two factors contribute towards the efficiency of drug treatment: the pharmacological action of the drug and the patient's belief in its efficacy. ${ }^{1}$ This belief is known as the placebo or non-specific factor. To measure its effect a no treatment control group is required. The experimental design gains strength if another group of subjects is included who receive the drug without being aware of its administration. There are ethical problems when drugs are administered without the recipients' awareness. Nevertheless, when subjects are told that they may or may not receive medication and give informed consent the deception becomes acceptable.

We have been able to test the effect of antistress medication in a training class. All police cadets in Western Australia are required to attend a necropsy demonstration, which they believe will be an unpleasant experience.

Among the $\beta$ adrenergic blocking agents, oxprenolol (Trasicor) has been shown to reduce the effects of transient anxiety. ${ }^{2-4}$ We therefore decided to examine the stress reducing effect of oxprenolol in a design which controlled for the effects of both medication and expectancy.

\section{Subjects, methods, and results}

The subjects were 63 men and five women (median age 20.2 years). They were seen as a group and the experiment was explained to them. The volunteers then completed two questionnaires, the "right now" form of the bipolar profile of mood states (POMS) and an anxiety questionnaire. ${ }^{5}$ They also signed a consent form which had been approved by the Human Rights Committee.

The class was split into three divisions, each of which attended a different

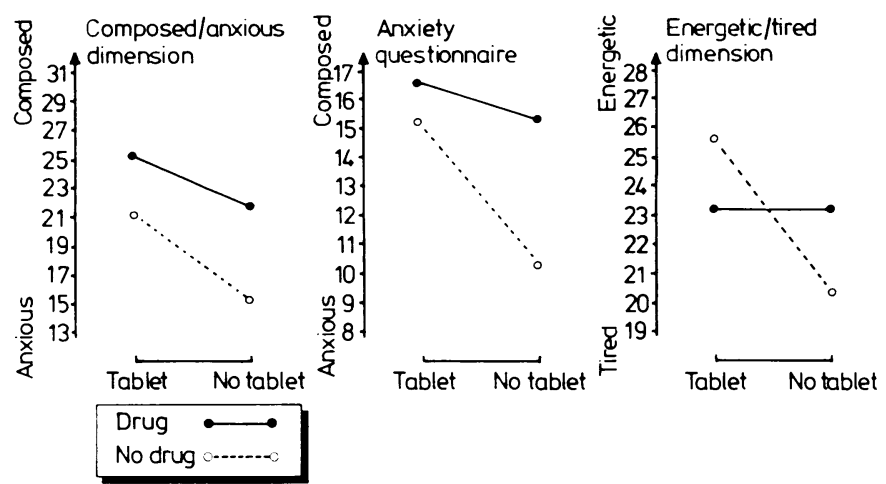

Mean scores on composed/anxious dimension, anxiety questionnaire, and energetic/tired dimension. Each point on each graph based on 17 different subjects.

necropsy demonstration. When the subjects arrived at the morgue they received $100 \mathrm{ml}$ orange juice, and half of them were given a placebo tablet. Half the number of subjects received $40 \mathrm{mg}$ oxprenolol in their orange juice. Hence there were four different treatment groups-(a) those who received oxprenolol and a tablet (medication plus belief); (b) those who received oxprenolol but no tablet (medication without awareness); (c) those who received no drug but a tablet (unmedicated but believed that they were); (d) those not given a drug or a tablet (unmedicated and aware that they were a no treatment control group). Allocation to the groups was at random and data were evaluated blind.

After the administration of orange juice with or without a tablet the cadets attended a brief lecture and 45 minutes later filed into the necropsy theatre where the body was lying. The subjects' pulse rate was recorded; they completed another POMS inventory and questionnaire and then watched the necropsy.

The mean heart rate of the subjects who received oxprenolol was $60 \cdot 1 / \mathrm{min}$, while that of the no drug groups was $72 \cdot 6$. This difference was highly significant $(\mathrm{F}=52.11 ; \mathrm{p}<0.001)$. There was no significant change in heart rate due to administration of the tablet.

The figure shows the mean composed/anxious and energetic/tired POMS scores and results of the anxiety questionnaire. Three analyses of covariance were performed. Subjects who received oxprenolol were significantly more composed $(F=6.71 ; p=0.012)$, as were those receiving a tablet $(F=6.77$; $\mathrm{p}=0.012$ ), with no significant interaction. This implies that the drug effect was independent of the non-specific effect. Similar results were obtained when the anxiety questionnaire data were analysed.

On the energetic/tired dimension oxprenolol did not affect the subjects' response $(F<1)$, but giving volunteers a tablet made them feel more vigorous $(\mathrm{F}=5 \cdot 43 ; \mathrm{p}=0.024)$

\section{Comment}

These results show that $40 \mathrm{mg}$ oxprenolol taken some 45 minutes before a stressful event reduces subjective anxiety. The pharmaceutical action of oxprenolol was independent of the additional, non-specific effect. Oxprenolol therefore seems to reduce transient stress without causing fatigue.

We are grateful to the Police Commissioner ( $\mathrm{Mr} \mathrm{J} \mathrm{H}$ Porter, QPM) for permitting police cadets to volunteer. Trasicor was made available by Ciba-Geigy Australia Limited.

\footnotetext{
1 Rickels K, comp, ed. Non-specific factors in drug therapy. Springfield: Thomas,

2 Taggert

(to stress. Lancet 1972;ii:256-8.

WP Oxprenolol in the treatment of anxiety due to environmental stress. Am f Psychiatry 1975;132:965-6.

Pocock DA, Landauer AA. Oxprenolol reduces transient stress. Med f Aust $1982 ;$ ii: 13

5 McNair D, Lorr M. Profile of mood states: bi-polar form (POMS-BI). San Diego Education and Industrial Testing Service, 1982.
}

(Accepted 8 fune 1984)

Department of Psychology, University of Western Australia, Nedlands 6009, Australia

ALI A LANDAUER, BA, PHD, senior lecturer

Department of Forensic Pathology, Queen Elizabeth II Medical Centre, Nedlands 6009, Australia

DEREK A POCOCK, MB, DMJ, forensic pathologist

Correspondence to: Dr Ali A Landauer. 